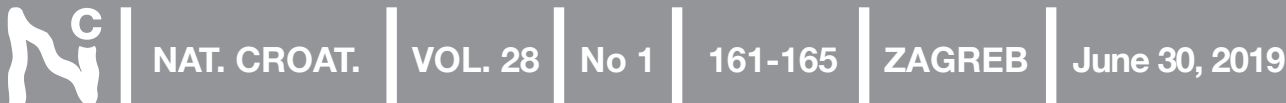

short communication / kratko priopćenje

DOI 10.20302/NC.2019.28.14

\section{NEW HERPETOFAUNAL DATA FROM CRES ISLAND, CROATIA}

\section{Peter Geissler ${ }^{1,2, *}$ \& Markus Grabert ${ }^{2}$}

${ }^{1}$ Museum Natur und Mensch, Freiburg, Gerberau 32, 79098 Freiburg, Germany

${ }^{2}$ State Natural History Museum Stuttgart, Rosenstein 1, 70191 Stuttgart, Germany

Geissler, P. \& Grabert, M.: New herpetofaunal data from Cres Island, Croatia. Nat. Croat. Vol. 28, No. 1., 161-165, Zagreb, 2019.

We provide new and supplementary data on the distribution and natural history of reptiles on the island of Cres: Dalmatolacerta oxycephala (range extension of an alien introduced population); Emys orbicularis hellenica (status of the population in the southwestern parts of Cres); Hemidactylus turcicus (first record after 38 years); Trachemys scripta elegans (first record on Cres).

Key words: Dalmatolacerta oxycephala, Emys orbicularis hellenica, Hemidactylus turcicus, Trachemys scripta elegans, Cres Island, Croatia, new records, natural history

Geissler, P. \& Grabert, M.: Novi herpetofaunistički podaci s otoka Cresa, Hrvatska. Nat. Croat. Vol. 28, No. 1., 161-165, Zagreb, 2019.

$\mathrm{U}$ radu donosimo nove i dodatne podatke o rasprostranjenosti te prirodoslovne podatke o gmazovima na otoku Cresu: Dalmatolacerta oxycephala (proširenje areala strane introducirane populacije); Emys orbicularis hellenica (status populacije na jugozapadnom dijelu Cresa); Hemidactylus turcicus (prvi nalaz nakon 38 godina); Trachemys scripta elegans (prvi nalaz za Cres).

Ključne riječi: Dalmatolacerta oxycephala, Emys orbicularis hellenica, Hemidactylus turcicus, Trachemys scripta elegans, otok Cres, Hrvatska, novi nalazi, prirodoslovlje

The herpetofauna of the Cres-Lošinj Archipelago has undergone several inventories during the last 35 years (BRuno, 1980, 1988; SeHnal \& SCHUSTER, 1999; Rathbauer, 2002; Tóth et al., 2006, 2009 a, b; Hill, 2008; Diekmann \& Diekmann, 2010; Bonte, 2012; То́тн et al., 2017 a, b).

On Cres, the largest island of the archipelago, surveys have recorded 23 species of amphibians and reptiles (То́тн et al., 2017b). It is followed by the island of Lošinj, with 14 species (То́тн et al., 2009b). The surrounding islets are only inhabited by one to three terrestrial reptile species and in one case also by one amphibian species (Bufotes viridis) (Tótн et al., 2009a, 2017b).

In the case of Cres, however, the current status and distribution of several additional species, mentioned by BRUNO (1980) remain unconfirmed (e.g. Bombina variegata, Emys orbicularis, Hemidactylus turcicus, Tarentola mauritanica, Lacerta trilineata, Podarcis siculus, Natrix tesselata, Vipera ammodytes) (Tóтн et al., 2006, $2017 \mathrm{~b}$ ). Interestingly, three of these species were recently recorded from Lošinj or other islets off the coast of Cres (e.g. L. trilineata, P. siculus, H. turcicus) (То́тн et al., 2017a).

* corresponding author: pgeissler84@yahoo.de 
We herein present data on yet unrecorded or unconfirmed reptile species from Osor and surrounding areas in the southwestern part of Cres. Our data is based on field trips between 1969 and 2013 by Markus Grabert and in May 2018 by Peter Geissler.

Dalmatolacerta oxycephala (Dumeril \& Bibron, 1839)

Tо́тн et al. (2006) were the first to record the presence this species on Cres. They found three specimens "on a stone wall bordering the channel that separates Lošinj and Cres" (То́тн et al., 2006). They stated that the specimens encountered were most likely introduced to this site. Diekmann \& Diekmann (2010) and Diekmann (2017) confirmed the presence of an established population along the mentioned wall in Osor. Kolodziej \& Proкоsch (2018), based on a personal comment of M. Schweiger, stated that there was a further expansion of this species without providing further information.

We can confirm the observations of the latter authors. In May 2018 up to 30 adult and subadult individuals were encountered along a $200 \mathrm{~m}$ long part of the old city wall between the channel and the ruins of the former St. Peter Monastery. Among them were egg bearing specimens (see Fig. 1), indicating that this northernmost population shows a reproductive seasonality similar to populations within the natural range (Bischoff, 1984). Two additional juvenile specimens were encountered on a house wall at the market square of Osor, demonstrating that the species is currently dispersing within the town of Osor, where it occurs syntopically with Podarcis melisellensis.

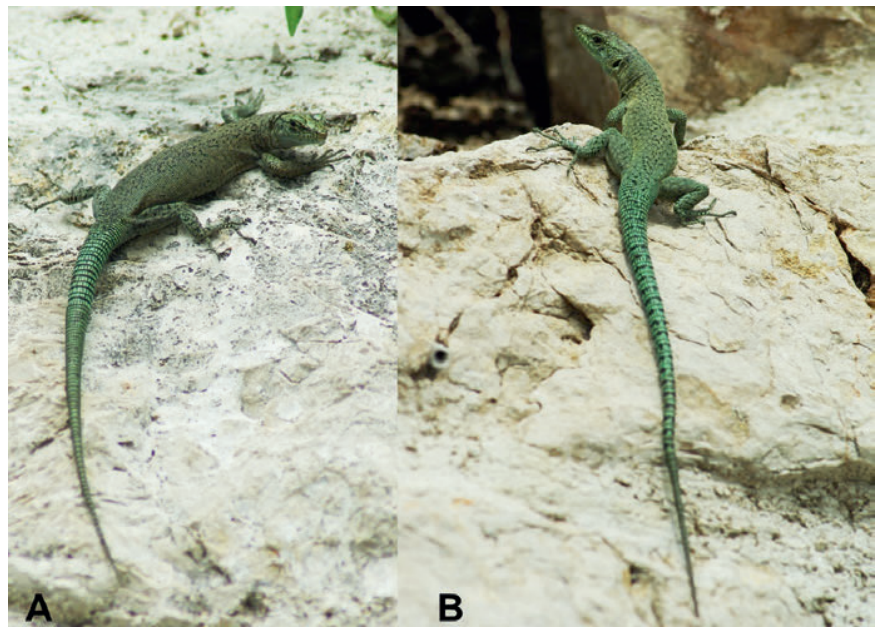

Fig. 1. Adult Dalmatolacerta oxycephala (Dumeril \& Bibron, 1839) in Osor, May $28^{\text {th }} 2018$ :

(A) Egg bearing female; (B) Male (photos: P. Geissler).

Emys orbicularis hellenica (Valenciennes, 1832)

The European pond turtle was previously known from three different regions on Cres: (1) Merag peninsula (Sehnal \& Schuster, 1999); (2) Lake Vrana (Bruno, 1980); (3) Zlatuja blato, three larger ponds east of Osor (BRUNO, 1980). According to TótH et 
al. (2006) newer records of this species are lacking from all three localities. RATHBAUER (2002) revisited the ponds near Osor in May 2002, without finding the species.

One of us (M. Grabert) regularly visited the mentioned ponds (about $700 \mathrm{~m}$ east of Osor, along the road to Punta Križa) between 1973 and 2013. In all three ponds, Emys specimens were present throughout this period of 40 years. Fig. 2C shows an assemblage of basking specimens of different ages in May 2013, indicating that the population reproduces regularly. Interestingly the water level within the ponds faces a strong seasonal fluctuation. In summer the ponds may even dry up completely, as shown in Fig 2.

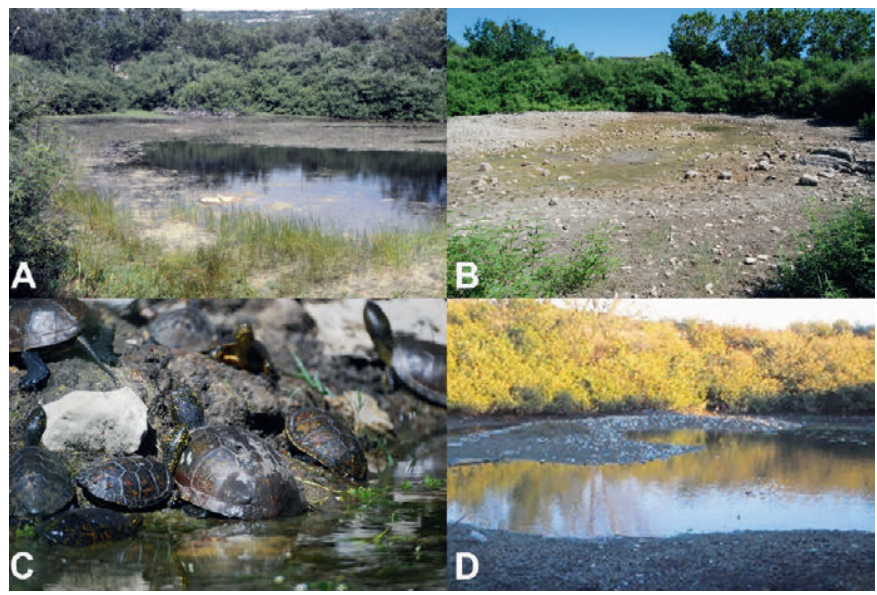

Fig. 2. Seasonal aspects of the Emys habitat near Osor: (A) May 1980; (B) June 2012; (C) basking adult and subadult Emys orbicularis hellenica (Valenciennes, 1832) in May 2013; (D) September 1997 (photos: M. Grabert).

In May 2018 we were able to encounter four adult specimens (Fig. 3). The pond still had a surface of about $150 \mathrm{~m}^{2}$ (up to $1 \mathrm{~m}$ in depth) and was densely covered with Ranunculus baudotii. No juveniles were encountered. The adults fit the characteristic traits of the subspecies Emys orbicularis hellenica (Valenciennes, 1832) as compiled by Fritz (1992, 2001). In 2018 the species occurred syntopically with Hyla arborea, Pelophylax ridibundus, Natrix natrix and Trachemys scripta elegans (see below).

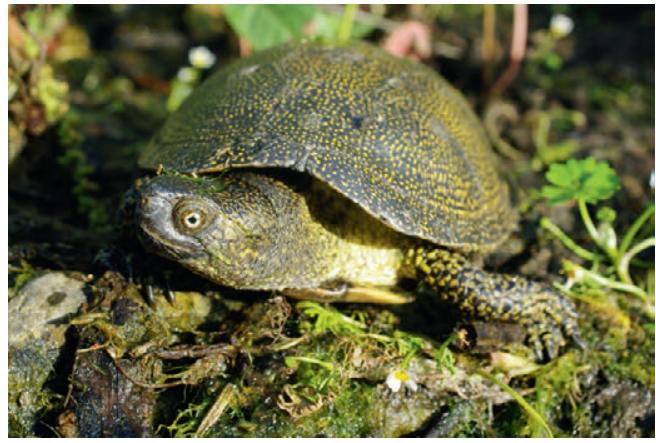

Fig. 3. Male Emys orbicularis hellenica (Valenciennes, 1832) near a pond east of Osor, May 29th 2018 (photo: P. Geissler). 
Hemidactylus turcicus (Linnaeus, 1758)

The presence of $H$. turcicus on Cres (Osor, Beli, Punta Križa) was first indicated by BRUNO (1980). However no later surveys were able to provide any confirmation or evidence that the species still occurs at other localities on the island (SEHNAL \& Schuster, 1999; Sehnal \& Schuster, 1999; Rathbauer, 2002, Tóth et al., 2006, Diekmann \& Diekmann, 2010; Tóth et al., 2017b; Kolodziej \& Proкosch, 2018). Tо́тн et al. (2006, 2017b) argued that this species might occur on Cres, as it is known from the surrounding islands of Susak (Тóтн et al., 2017a), Plavnik (BRuno, 1980), and Lošinj (То́тн et al., 2006, 2009b), but that substantiated records are lacking.

M. Grabert observed one single adult specimen in May 2003, at the cathedral of Osor (Fig. 4A). In May 2018 we were able to encounter eight specimens (two juveniles and six adults) of $\mathrm{H}$. turcicus on five different house walls scattered in different streets of Osor (see Fig. 4B).

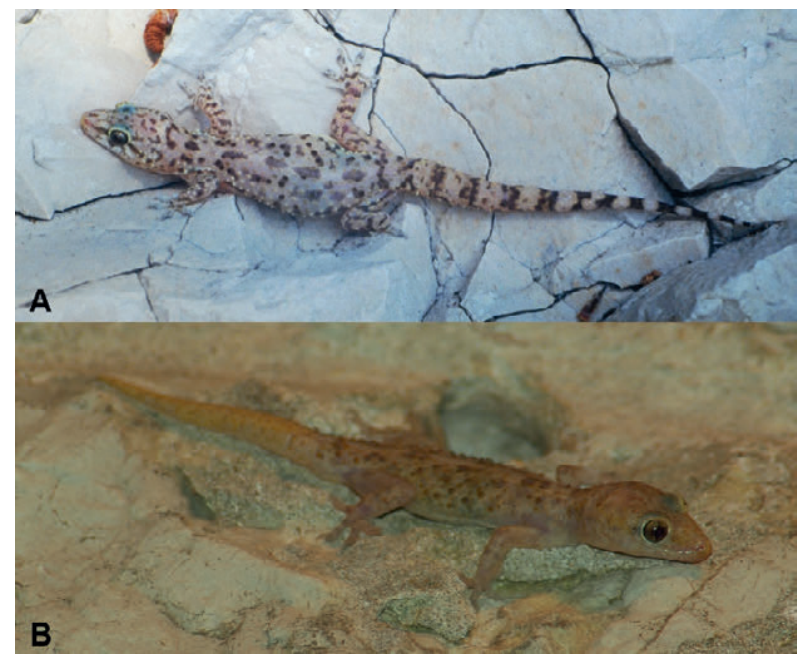

Fig. 4. Adult Hemidactylus turcicus (Linnaeus, 1758) from Osor: (A) observed behind the Cathedral in May 2003; (B) observed on a house wall in the city center, June 1st, 2018 (photos: M. Grabert (A); P. Geissler (B)).

\section{Trachemys scripta elegans (Wied-Neuwied, 1838)}

On May $29^{\text {th }} 2018$ P. Geissler observed one adult female specimen of Trachemys scripta elegans basking on the edge of a pond mentioned in the Emys orbicularis account above. This is the first record of this species from Cres. Most likely the observed specimen is a released pet. Further observations are needed, to clarify if there are more specimens present in the ponds near Osor, and if they form a reproducing population. In recent years, stable populations of Trachemys scripta elegans have been recorded in several areas of the northern Adriatic region, including on the neighboring island of Krk (VAMBERger et al., 2008; Jelić \& Jelić, 2015; SCHWEIGER, 2015)

Acknowledgements. PG cordially thanks Rike Bach for her support during the field trip in 2018 as well as Julia Habermann for her help in processing the figures. 


\section{REFERENCES}

Bischoff, W., 1984: Lacerta oxycephala-Spitzkopfeidechse. In Böнмe, W. (eds.), Handbuch der Reptilien und Amphibien Europas, Bd 2/I. Echsen II (Lacerta). Aula-Verlag Wiesbaden. p. 301-317.

Bonte, C., 2012: Affirmation of Coronella austriaca (Laurenti, 1768) on the island of Cres, Croatia. Herpetology Notes 5, 65-66.

Bruno, S., 1980: l'erpetofauna delle isole di Cres, Trstenik, Plavnik e Krk (Kvarner, Jugoslavija). Atti del museo Civico di Storia naturale di Trieste 31, 249-282.

BRuno, S., 1988: l'erpetofauna delle isole di Cres, Krk e Ada (Jugoslavia-Albania). Bulletin d'écologie, Paris 19 (2-3), 265-281.

Diekmann, M. \& Diekmann, K., 2010: Die mythischen Inseln: Cres und Lošinj. Draco 42, 40-53.

Dieckmann, M., 2017: Die Kvarner-Bucht. Eine Schnittstelle zwischen den Ökosystemen Europas. Terraria-Elaphe 2017 (2), 26-33

Fritz, U., 1992: Zur innerartlichen Variabilität von Emys orbicularis (Linnaeus, 1758). 2. Variabilität in Osteuropa und Redefinition von Emys orbiculars orbicularis (Linnaeus, 1758) und E. o. hellenica (Valenciennes, 1832). Zoologische Abhandlungen des Museums für Tierkunde Dresden 47 (5), 37-78.

FrITz, U., 2001: Emys orbicularis (Linnaeus, 1758) - Europäische Sumpfschildkröte. In FrITz, U. (eds.), Handbuch der Reptilien und Amphibien Europas Bd 3/IIIA Schildkröten (Testudines) I. Aula Verlag Wiesbaden. p. 343-515.

Kolodziej, K. \& Proкosch, P., 2018: Nord-Kroatien - Eine herpetologische Fotosafari. Terraria/elaphe 40-50.

Hill, J., 2008: Coronella austriaca (Laurenti, 1768) from the Croatian Island of Cres. Herpetozoa 20 (3/4), 192

Jelić, L. \& Jelić, D., 2015: Allochthonous species of Turtles in Croatia and Bosnia and Hercegovina. Hyla 2015/1, 53-64.

RAthbauer, F., 2002: Feldherpetologische Exkursion nach Cres (2002). ÖGH-Aktuell 10, 6-10.

Sehnal, P. \& Schuster, A., 1999: Herpetologische Beobachtungen auf der Kvarnerinsel Cres, Kroatien. Ergebnisse von fünf Exkursionen. Herpetozoa 12 (3/4), 163-178.

SchweIger, M., 2015: First record of breeding of the alien turtle species Trachemys scripta elegans in the wild on the island of Krk, Croatia? Hyla 2015/1, 50-52.

Tóth, T., Grillitsch, H., Farkas, B., Gál, J. \& Sušić, G., 2006: Herpetofaunal data from Cres island, Croatia. Herpetozoa 19 (1/2), 27-58.

Tóth, T., Farkas, B., Géczy, C.S., Sós, E., Halpern, B. \& Molnár, Z., 2009a: Herpetofaunal data from Ilovik and neighboring islets (Cres-Lošinj Archipelago, Croatia). Herpetozoa 22 (1/2), 82-87.

Tóth, T., GÉczy, C.S., Sós, E., Molnár, Z. \& HAlpern, B., 2009b: Further data on the herpetofauna of Lošinj island, Croatia. Herpetozoa 21 (3/4), 192.

Tóth, T., Heltai, M., Keszi, A., Sušić, G., Moharos, L., Farkas, B., Géczy, G., Torda \& Gál, J., 2017a: Herpetofauna inventory of the small islands os the Cres-Lošinj Archipelago (North Adriatic Sea, Croatia). Herpetozoa 30 (1/2), 21-28.

Tóth, T., Boksai, D., Géczy, C., Mihalyi, A., Takacs, R., Sušić, G., Vinczek, J., Gál, J., Marosán, M., Farkas, B., Bokis, A. \& Heltai, M., 2017b: Road-killed snakes on the island of Cres (Croatia). Biharean Biologist 11 (2), 88-93.

VAmberger, M., LipovšEK, G. \& Gregorić, M., 2012: First reproduction record of Trachemys scripta (Schoepff, 1792), in Slovenia. Herpetozoa 25(1/2), 76-79. 
